International Small Business Journal

Copyright (C) 2008 SAGE Publications

(Los Angeles, London, New Delhi and Singapore)

http://isb.sagepub.com

[DOI: 10.1 I 77/0266242607086574]

Vol 26(2): 000-000

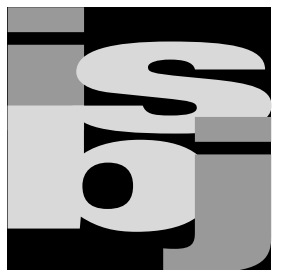

\title{
UK Export Performance Research
}

Review and Implications

\author{
COLIN WHEELER \\ University of Portsmouth, UK \\ KEVIN IBEH \\ University of Strathclyde, UK
}

\author{
PAVLOS DIMITRATOS \\ Athens University of Business and Economics, Greece
}

Previous research on export performance has been criticized for being both a mosaic of autonomous endeavours and for a lack of theoretical development. Building upon extant models of export performance, and a review and analysis of research on export performance in the UK for the period 1990-2005, an integrated model of export performance is developed and theoretical explanations of export performance are put forward. It is suggested that a multi-theory approach to explaining export performance is viable. Management and policy implications for the UK emerging from the review and synthesis of the literature and the integrated model are discussed.

KEYWORDS: integrated model; UK export performance

\section{Introduction}

Most previous integrative reviews of export performance research (e.g. Aaby and Slater, 1989; Zou and Stan, 1998) synthesize studies from all over the world with little attempt to identify the effects of country-specific issues. It seems to be assumed that country conditions, or 'export climates' (see Holzmuller and Stottinger, 1996), are broadly the same, and that there are no country-specific influences on firms' export performance. Yet, there exists a widespread recognition of the importance of country environments - economic, institutional and cultural environments (Dunning, 1988); factor conditions (Porter, 1990); national resource asymmetries (Fahy, 2001); country-of-origin effects (Balabanis and Diamantopoulos, 2004) - on firms' economic performance, including export performance (Das, 1994; Morgan and Katsikeas, 1998; Sullivan and Bauerschmidt, 1989; Tesfom and Lutz, 2006; 
Westhead et al., 2001; Whitelock and Jobber, 1999; Zahra et al., 1997). Stottinger and Holzmuller's account seems particularly instructive. Using an export performance model developed among Austrian firms, these researchers attempted to explain the drivers of export performance for US firms, but found a very different set of influential factors. They concluded that export performance 'is strongly influenced by background variables from the local business environment' (Stottinger and Holzmuller, 2001: 23).

This may explain the increasing emergence of country/region-specific integrative reviews of export behaviour research in the literature, including the respective reviews of European, Italian, Brazilian and African export behaviour studies by Ford and Leonidou (1991), Bonaccorsi (1994), Da Rocha and Christensen (1994), and Tesfom and Lutz (2006). These integrative reviews have provided a number of important country/region-specific insights, including Ford and Leonidou's (1991:2) observation of 'a significantly different conceptual approach to marketing research in Europe' - arising from the International Marketing and Purchasing Group (IMP) approach to studying relationships rather than the marketing mix approach; Tesfom and Lutz's (2006: 277) conclusion that developing country exporters are particularly plagued by 'the country of origin barrier'; and, Bonaccorsi's (1994) finding that many small Italian exporters tend to allocate little or no resources to formal international market planning and research and limit their international commitment to exporting through close personal relationships with agents and representatives. Da Rocha and Christensen (1994) also reported that Brazilian exporters faced particular difficulty with finding export intermediaries and, thus, tended to leave foreign importers in charge of marketing activities while concentrating on the production side of export activity. This followed unsuccessful attempts by the Brazilian government to establish new types of intermediaries, notably export cooperatives and export trading companies.

It is arguable that a comparable integrative review might highlight similar distinctive aspects of export performance in the UK context. Such review effort also seems eminently sensible given its potential to cast light on the widely reported underperformance of British firms in outward internationalization relative to their counterparts from other advanced economies, including the USA, Canada, Germany, Italy, and Japan (Beamish et al., 1993; Diamantopoulos and Schlegelmilch, 1994; McGuinness et al., 1991; Morgan and Katsikeas, 1998).

The foregoing provides the rationale for this study, which focused on the UK export performance research published during the period 1990-2005. This is in the belief that the more recent research has a greater likelihood of capturing the probable effects of recent developments in the UK exporter's environment and providing more useful empirical insights on some of the topical issues confronting exporting scholars as well as policy makers at national, regional and corporate levels. It is also envisaged that reviewing more current research would highlight the aspects of export behaviour that are being investigated and those that are receiving little or no attention. This knowledge may be useful in influencing future exporting research agenda in the UK.

The key questions explored in the present study, therefore, were: What does recent relevant empirical research tell us about the key influences on the export 
performance of UK firms? How different are these from the earlier conclusions reached in the broader export performance research? Which aspects of export performance are being investigated and which aspects are receiving little or no attention? Which factors may account for the observed relative under-performance of UK exporting firms and how might this be redressed? How should policy makers and business leaders, at national, regional, and corporate levels, respond to the aggregate insights from recent UK performance research? Which emerging issues should export performance scholars focus on and what new approaches should they adopt?

The remainder of this article is structured as follows. The next section draws upon the previous relevant work to explain and justify the present study's approach and methodology, culminating in a proposed holistic framework of export performance. The third section presents and discusses the study's findings, making appropriate references to the literature. The final section highlights the implications of the study's findings for theory development, managerial and policy decisionmaking and for future research.

\section{Review Approach and Methodology}

Articles were included if they met the following criteria. First, they were published in the period 1990 to 2005; and second, they investigated the performance of exporters in the UK, drawing upon quantitative or qualitative data. The first step in the search process was to use Internet-based resources including ABI/INFORM, MCB Emerald and Zetoc electronic databases. The search terms included exporting, export performance, export marketing strategy, export channels, export networks, and UK. In some instances, full-text articles were only available from 1994, so copies of the articles were obtained manually. The search also extended to journal and publishers' websites and manual searches were made of books and references in articles collected. In all, 33 studies met the criteria for inclusion. The analysis of the articles was carried out by the authors; with the results agreed by them. Most of the studies were designated as having been carried out in the UK as a whole.

\section{Measures of Export Performance}

Among the many challenges of integrating the research on export behaviour is the issue of measuring export performance. It can, indeed, be argued that researchers' attempts to heed Aaby and Slater's (1989:23) rousing charge of establishing 'what is known' and widening the range of 'solid conclusions' about firm export behaviour (hence rid the field of its fragmentary label) have faltered on the altar of these disparate export performance measures. Cavusgil and Zou (1994) have listed the export performance measures used in previous research studies as including: export sales level; export sales growth; export profits; ratio of export sales to total sales; ratio of export profits to total profits; increase of importance of export to total business; overcoming barriers to export; propensity to export; acceptance of product by export distributors; export involvement; exporter internationalization; and, attitudes toward export. 


\section{International Small Business Journal 26(2)}

One obvious reason for this divergence is that the export behaviour research encompasses studies of firms at different levels of the export development process, namely pre-export, initial, and advanced (Leonidou and Katsikeas, 1996). While the qualitative/non-financial/subjective measures appear to be mainly used for studies involving, wholly or partly, firms at the pre- and initial exporting stages, the quantitative/financial/objective measures are, in general, associated with studies of firms at more advanced stages of export development. The Experf scale by Zou et al. (1998) seems to have advanced the search for generally acceptable export performance measures. This scale, which comprises financial/objective measures (i.e. sales, profits and growth), non-financial/subjective measures (i.e. perceived success, satisfaction and goal achievement), and a composite measure of export performance, has arguably bridged the dichotomy between the quantitative and qualitative export performance measures, thus providing an appropriate measurement spectrum for firms at different stages of export and internationalization development process (see Matthyssens and Pauwels [1996] and Zou and Stan [1998] for a sound description of each of these measures). The empirical validation of this scale by Styles (1998), using cross-national (UK and Australia) empirical evidence, and its adoption in Zou and Stan's (1998) rigorous integrative review, has arguably strengthened the value of the scale as an encompassing measure of export performance. It is, therefore, applied in this article in integrating the export performance of UK firms.

\section{Independent Factors Investigated}

Another major challenge associated with integrating the research on export performance is the diversity of independent variables investigated. There is, indeed, no better illustration of the reluctance of export behaviour researchers to build upon previous effort (i.e. 'a mosaic of autonomous endeavours'; Aaby and Slater, 1989: 7) than the situation with the selection of independent variables, and the lack of consistency in the way in which these variables have been measured. A major contributory factor to this is the disparate nature, or complete absence in some studies, of an underlying theory to guide the choice of independent variables (Zou and Stan, 1998).

It is gratifying to note, however, that the overall trend in export behaviour research is toward greater theoretical sophistication, and more importantly, building upon previous theoretical frameworks. For example, the studies by Chetty and Hamilton (1993), Styles and Ambler (1994), and Zou and Stan (1998) all supported, and built upon, Aaby and Slater's (1989) 'Strategic Export Model'. This model, which is rooted in the organizational capability/strategic management/resourcebased view of the firm, essentially presents export performance as driven by internal factors, including firm characteristics, competencies, and strategy. This, to be sure, resonates with the focus by resource-based theorists on the firm as a unique bundle of tangible and intangible controllable 'resources' (assets, capabilities, processes, managerial attributes, information and knowledge), which enable the conception and implementation of strategies aimed at improving firm efficiency and effectiveness (Barney, 1991; Wernerfelt, 1984; Zou and Stan, 1998).

Later theory building effort has complemented Aaby and Slater's (1989) model in two major respects. First, Styles and Ambler (1994) have drawn from industrial 
marketing/interaction/network theory to advance a hybrid model of export performance, which gave greater prominence to the importance of network/relationships factors in export performance. This reflects the understanding that a firm's success in entering new international markets may depend on its existing relationships with market actors (customers, suppliers, competitors, family, friends and private and public support agencies), both domestic and international; these relationships may offer contacts and help toward developing new partners and positions in new markets, or may restrict the nature of a firm's growth initiatives (Axelsson and Easton, 1992; Johanson and Mattsson, 1988).

Second, Zou and Stan (1998) have, in their integrative work, drawn from the Industrial Organization theory (IO) to further highlight the influence of external environmental factors on export performance. Although these authors' review evidence appeared not to fully support the IO's view of external factors and firm's export strategy as the primary determinants of export performance (Scherer and Ross, 1990; Zou and Stan, 1998), sufficient indications were obtained to underscore the need for greater research into the effect of external factors on firm export behaviour.

There is no gainsaying the usefulness of the insights provided by the outlined theoretical streams in further illuminating firm-level export behaviour. As observed by Bell et al. (2004), greater understanding of firm export (and internationalization) behaviour can be gained by exploring and exploiting the complementarities among relevant theoretical perspectives (see also Coviello and McAuley, 1999). The integrative review undertaken in this present article is, therefore, organized around a holistic framework, which draws from relevant previous works (Aaby and Slater, 1989; Styles and Ambler, 1994; Zou and Stan, 1998), including their underlying theoretical bases; these are the resource-based view of the firm (Barney, 1991; Wernerfelt, 1984), the network/interaction theory (Axelsson and Easton, 1992; Johanson and Mattsson, 1988), and the industrial organization theory (Collis, 1991; Scherer and Ross, 1990).

\section{The Proposed Framework}

As can be seen from Figure 1, the proposed framework identifies two broad categories of factors - internal and external environmental factors - as underpinning firm-level export performance. The internal environment of the firm is conceptualized as comprising three sets of factors, namely management-related attributes and resources; firm characteristics and resource base; and, firm competencies and strategies, including export marketing and relational strategies. The external environment is viewed as encompassing the relevant industry, domestic and foreign market environments, replete with their mixed offering of opportunities and threats/ problems. As implied by the direction of the arrows in Figure 1, these external factors are thought to have only indirect effects on firm export performance, through their impact on elements of the firm's internal environment (Cavusgil and Zou, 1994). Export performance (defined along the increasingly accepted three-dimensional Experf scale - see earlier discussion) is, therefore, thought to result from the relative effectiveness of the firm in applying and transforming the available (or accessible) resources and capabilities into competencies and strategies that best optimize the 
International Small Business Journal 26(2)

\begin{tabular}{|c|c|c|}
\hline $\begin{array}{l}\text { FIRM INTERNAL } \\
\text { ENVIRONMENT }\end{array}$ & $\begin{array}{l}\text { FIRM EXTERNAL } \\
\text { ENVIRONMENT }\end{array}$ & \\
\hline $\begin{array}{l}\text { CHARACTERISTICS AND } \\
\text { RESOURCE BASE } \\
\text { Management attributes and } \\
\text { resources } \\
\text { Firm characteristics and } \\
\text { resources }\end{array}$ & $\begin{array}{l}\text { EXTERNAL OPPORTUNITIES } \\
\text { Industry characteristics } \\
\quad \text { Networks } \\
\text { Domestic market characteristics } \\
\text { government factors }\end{array}$ & $\begin{array}{l}\text { Financial measures } \\
\text { Sales measures } \\
\text { Profit measures } \\
\text { Growth measures }\end{array}$ \\
\hline $\begin{array}{l}\text { COMPETENCIES AND } \\
\text { STRATEGIES } \\
\text { Export marketing strategies } \\
\text { Relationship-based strategies }\end{array}$ & $\begin{array}{l}\text { EXTERNAL THREATS/PROBLEMS } \\
\text { Industry characteristics } \\
\text { Domestic market characteristics } \\
\text { Foreign market characteristics }\end{array}$ & $\begin{array}{l}\text { Goal achievement } \\
\text { Composite scales }\end{array}$ \\
\hline
\end{tabular}

Figure 1. A Proposed Integrative Framework of Export Performance

opportunities in the external environment, while minimizing exposure to external threats/problems.

It is worth highlighting that these competitive resources and competencies (Piercy et al.,1998) may arise not only from the internal environment, but also from external sources. Network-related advantages, as Figure 1 shows, are a good example of factors that bridge the internal-external divide. Where the firm achieves significant export performance benefits through its proactive roles in developing and leveraging useful inter-firm and firm-to-customer relationships, including 'inward and outward links' (Crick and Jones, 2000), such competency would be regarded as internal. However, where useful exporting initiatives/links are originated, instigated, activated by an outside agency (e.g. industry association or government agency), the benefits should be viewed as externally-derived.

\section{Review Results}

\section{Overview of the Reviewed Studies}

As indicated earlier, the review is based on 33 studies, which are summarized in Table 1 . The table provides information about the size of sample; industry context of the study; type of firms sampled, data collection methods; response rate; analytical approaches; unit of analysis; whether an explicit theoretical basis is followed and whether hypotheses are used; measures of export performance and independent factors investigated. Twenty-four or $75 \%$ of the studies were published between 1997 and 2005, which would suggest that interest in export performance in the UK is increasing.

Sample size varied between 10 and 1,087 reflecting the mix of qualitative and quantitative methods used in the UK studies under review. The mail survey was the predominant data collection method and most of the mail survey studies had a sample size of more than a hundred, which appears to be adequate for the analysis undertaken. Response rates varied between $16 \%$ and $71 \%$, with most of the studies reporting rates of more than 30\%. Five studies: Oakley (1996), Katsikeas et al. (1997), Crick and Jones (2000), Keeble et al. (1998), McAuley (1999) used personal 
Wheeler et al.: UK Export Performance: Review and Implications

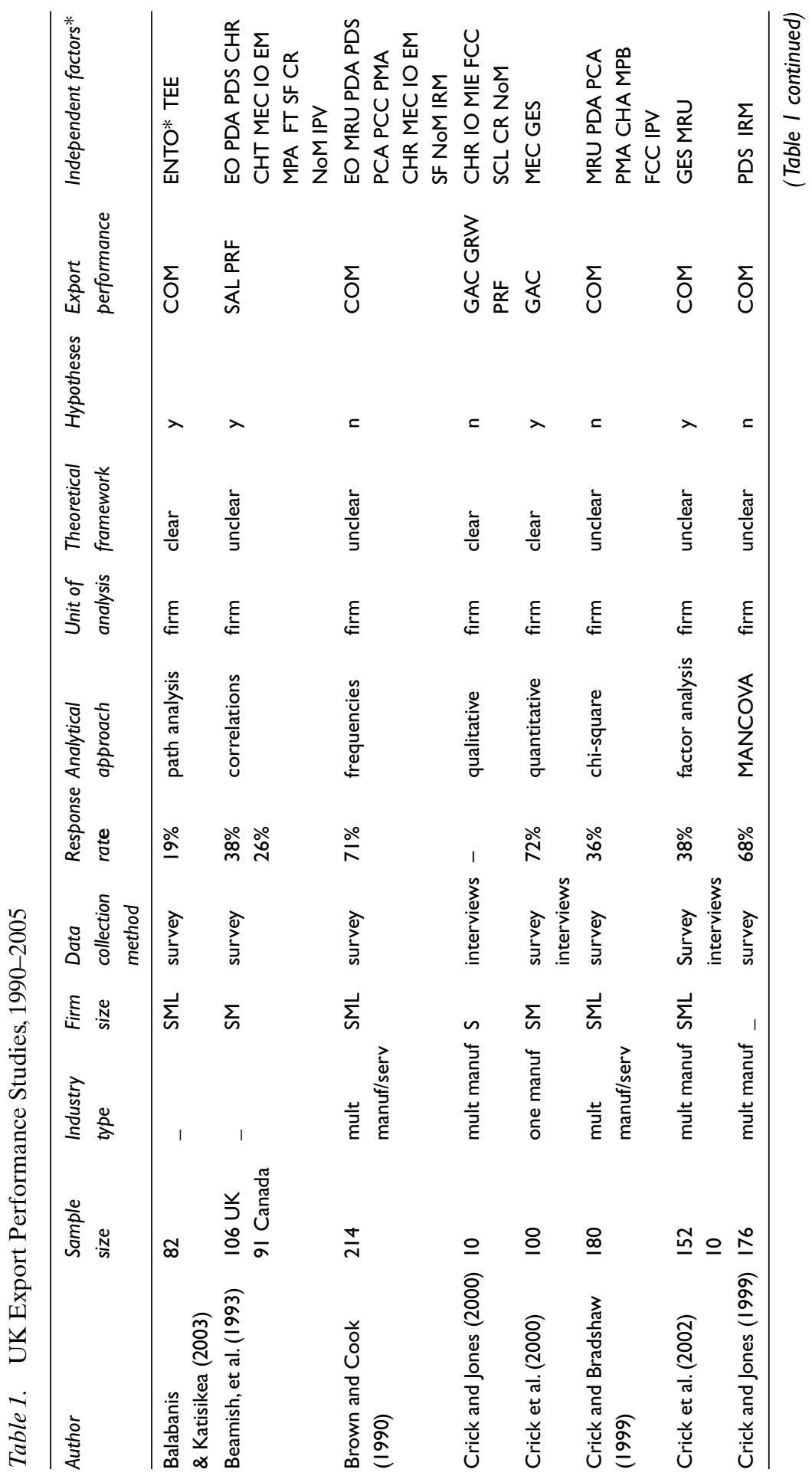


International Small Business Journal 26(2)

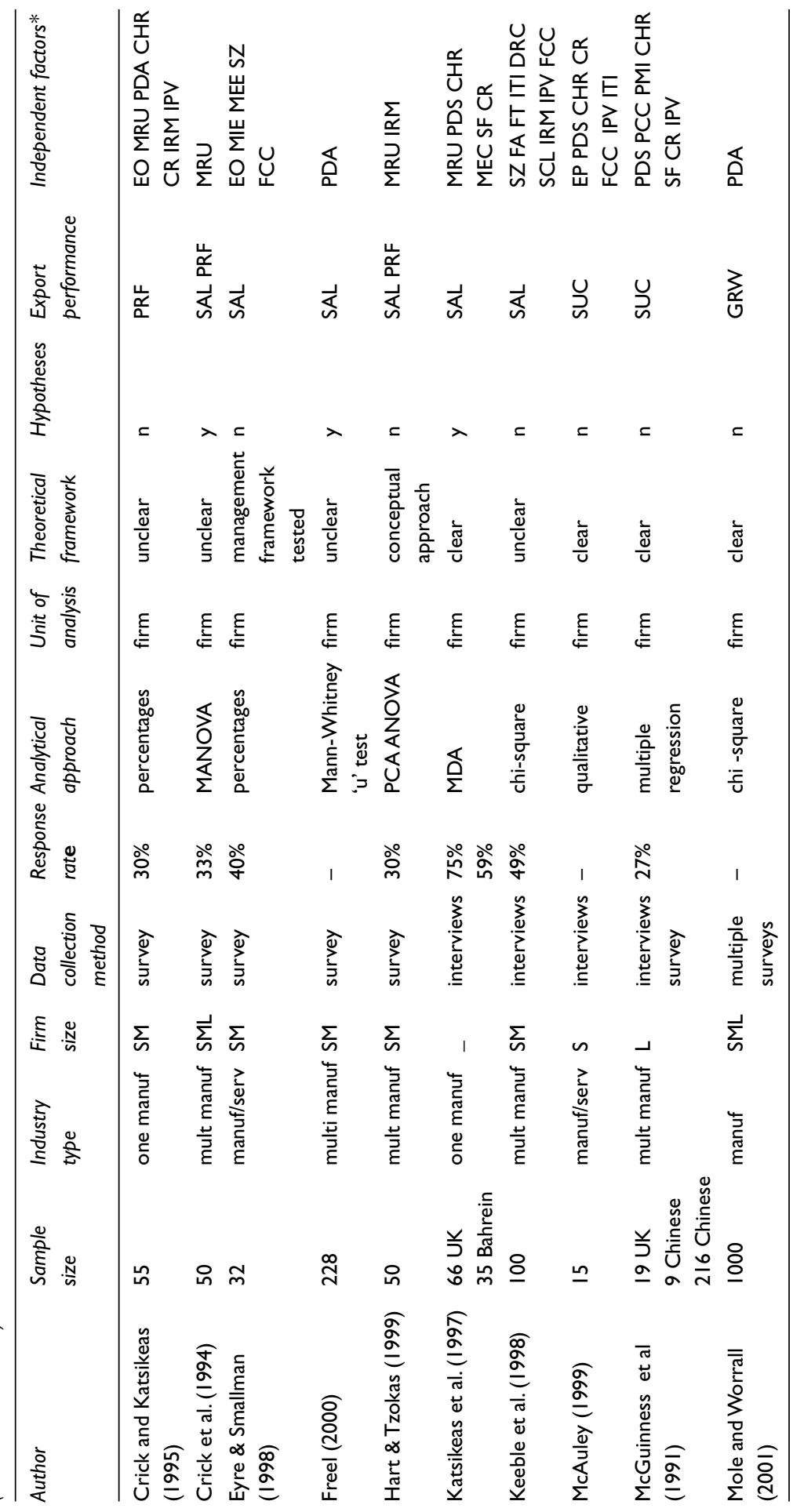


Wheeler et al.: UK Export Performance: Review and Implications

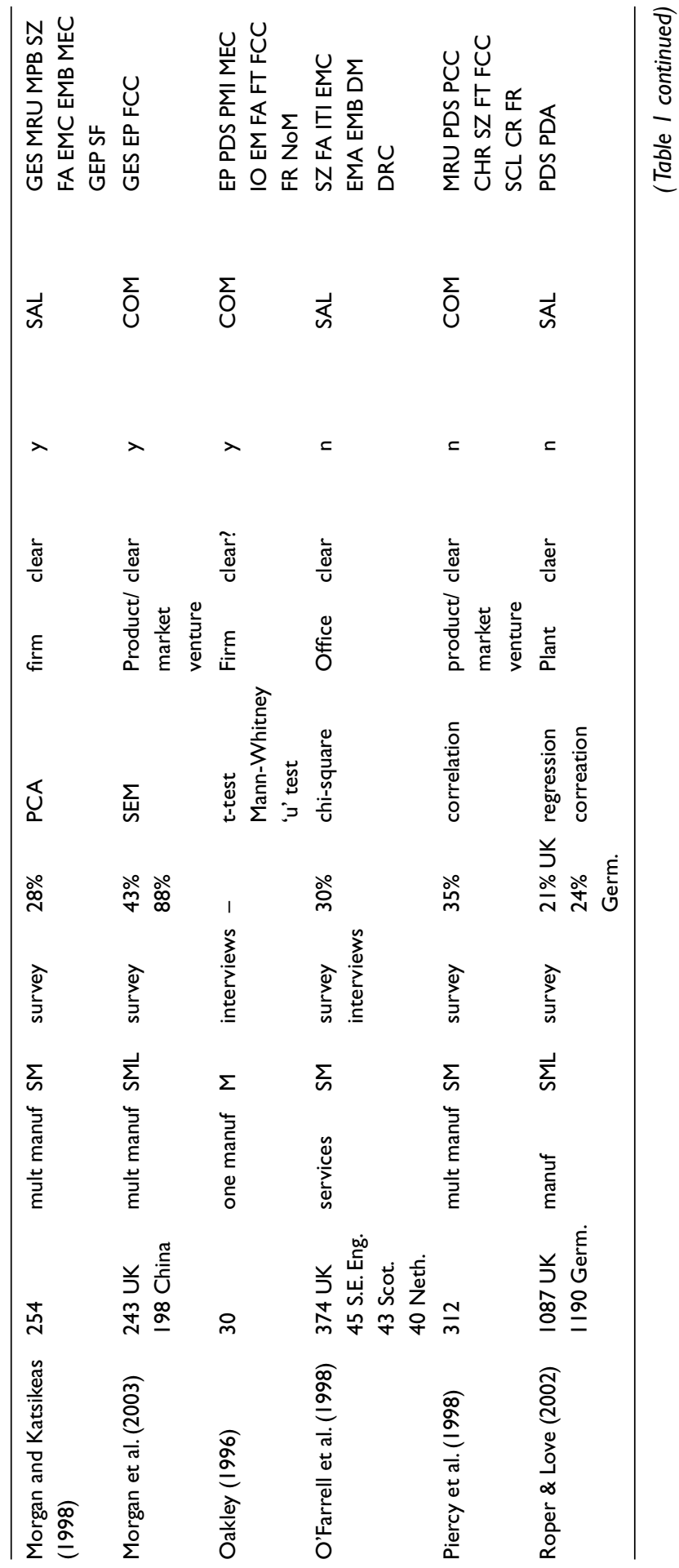


International Small Business Journal 26(2)

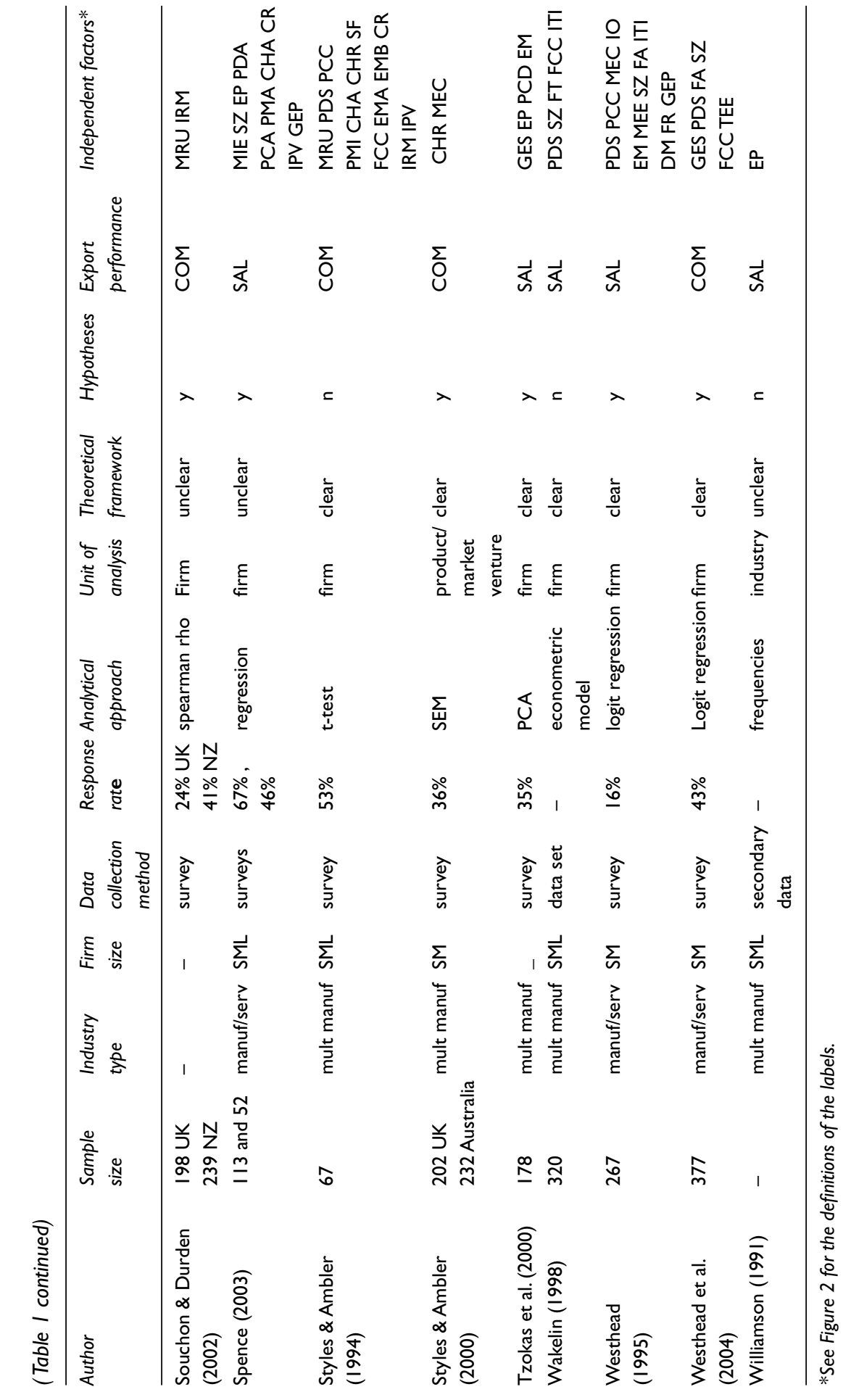


interviews; while another four: McGuinness et al. (1991), O'Farrell et al. (1998), Crick et al. (2000) and Crick et al. (2002) combined personal interviews with a mail survey. A wide range of analytical approaches, ranging from simple to complex quantitative techniques and qualitative analysis, are represented. The more complex approaches include structural equation modelling, principal component and regression analyses. Qualitative analysis is used by McAuley (1999) and Crick and Jones (2000).

The unit of analysis in the majority of studies was the firm and in one instance plant level (Roper and Love, 2002). (These are mostly manufacturing firms - only one study investigated service firms). It is notable that in spite of the well-known problems associated with assessing export performance at the firm level, only three studies, Morgan et al. (2003), Piercy et al. (1998) and Styles and Ambler (2000), analysed activities at the product/market venture level. The study of service firms by O'Farrell et al. (1998) was conducted at the office level. Finally, it should be noted that many of the articles published from 1997 onwards have a clear theoretical basis, suggesting there is more theoretical development later in the review period. It would seem that calls for more theoretical development of the subject are being heeded (Zou and Stan, 1998).

\section{The Effects of Independent Factors on Export Performance}

Table 2, shows the aggregate findings from export performance research undertaken among UK firms during the 1990-2005 period. The independent factors investigated fall under four major categories, namely (1) management-related attributes and resources; (2) firm characteristics and resources; (3) firm competencies and strategies (including export marketing and relational strategies); and, (4) firm external environmental (including industry, domestic, and foreign market) characteristics. While categories 1-3 comprise factors that are internal to the firm, the fourth category includes the external, largely uncontrollable factors. It is arguable that this four-part classification represents a fair attempt at achieving a parsimonious and meaningful integration of the existing schemes for grouping independent export performance factors in the literature (see Aaby and Slater, 1989; Styles and Ambler, 1994; Zou and Stan, 1998). It is helpful, also, that the categories are sufficiently flexible to accommodate factors from several theoretical streams, including the resource-based view of the firm, the network/interaction theory, and the industrial organization theory.

As indicated earlier, the dependent variable is not the single, or omnibus, export performance measure used, notably, in Chetty and Hamilton's (1993) study. Rather, this study has followed Zou and Stan's (1998) example in ensuring that the observed effects (positive, negative, or insignificant) of each independent factor are specified for the various dimensions of export performance explored in the UK studies under review. As Table 2 suggests, the investigated dimensions are mainly the financial (export sales, export profits, export growth) and the composite measures. The non-financial measures (perceived export success, satisfaction, goal achievement) would appear to have received less attention in UK export performance studies undertaken during the 1990-2005 period. Indeed satisfaction as a measure was not used in any of the studies under review. 


\section{International Small Business Journal 26(2)}

It is worth highlighting, also, that consistent with previous integrative reviews (Aaby and Slater, 1989; Chetty and Hamilton, 1993; Madsen, 1987; Zou and Stan, 1998), the bulk of the findings on the determinants of firm export performance in the UK relates to the internal environment. As is evident from the latter sections of Table 2, relatively few studies reported findings on the influence of external environmental factors on export performance. This reflects the dominant view of exporting as an internally-driven activity, and reinforces the widespread tendency to overlook (Madsen, 1987) or assume away the not easily measured effects of uncontrollable external factors on export performance (e.g. Aaby and Slater, 1989).

\section{Internal Environmental Factors}

These encompass three categories of factors. The first set relates to the attributes and resources embodied in the top management. Often-investigated variables here include management commitment, motivation, attitudes and perceptions regarding exporting, management international orientation and experience, including education. The second category of factors comprises the characteristics and resources associated with the firm itself, including size, age, technological and financial resources and other firm-specific capabilities. The third type of internal factors - firm competencies and strategies - are also firm-specific, but the focus is not on resource base (as in category two), but on how effectively and uniquely these resources/capabilities are configured and applied to offer superior customer value and improve firm competitive position. Independent factors related to aspects of export marketing strategy and the relationship-based strategy have been included within this category. This is based on the understanding that strategy selection decisions generally involve conscious effort to optimize benefits from the resources/capabilities available or accessible (e.g. network-related advantages) to the firm. Aggregate findings regarding each of the above categories of factors are now discussed.

Management-related Attributes and Resources Factors within this category appear to have received considerable attention within the UK export performance studies reviewed. As Table 2 shows, the eight independent factors investigated were management export commitment, international orientation, export motivation, management perception of export advantages, management perception of export barriers, entrepreneurial orientation, management international experience, and management education/experience. A number of important conclusions can be highlighted based on the aggregate analysis. The first is that favourable and supportive attitudes (including perceptions, motivations, and commitment) to exporting on the part of the firm's top management seem to have strong positive effects on the export sales, export profits and the composite measures of export performance. This also reflects the review evidence regarding the impact of the quality of managerial resources, including management education/background experience, international orientation and international experience, on firm export performance in the UK. It should be added that for management export commitment, international orientation and international experience, the positive findings reported relate to financial and non-financial measures of export performance, 
Wheeler et al.: UK Export Performance: Review and Implications

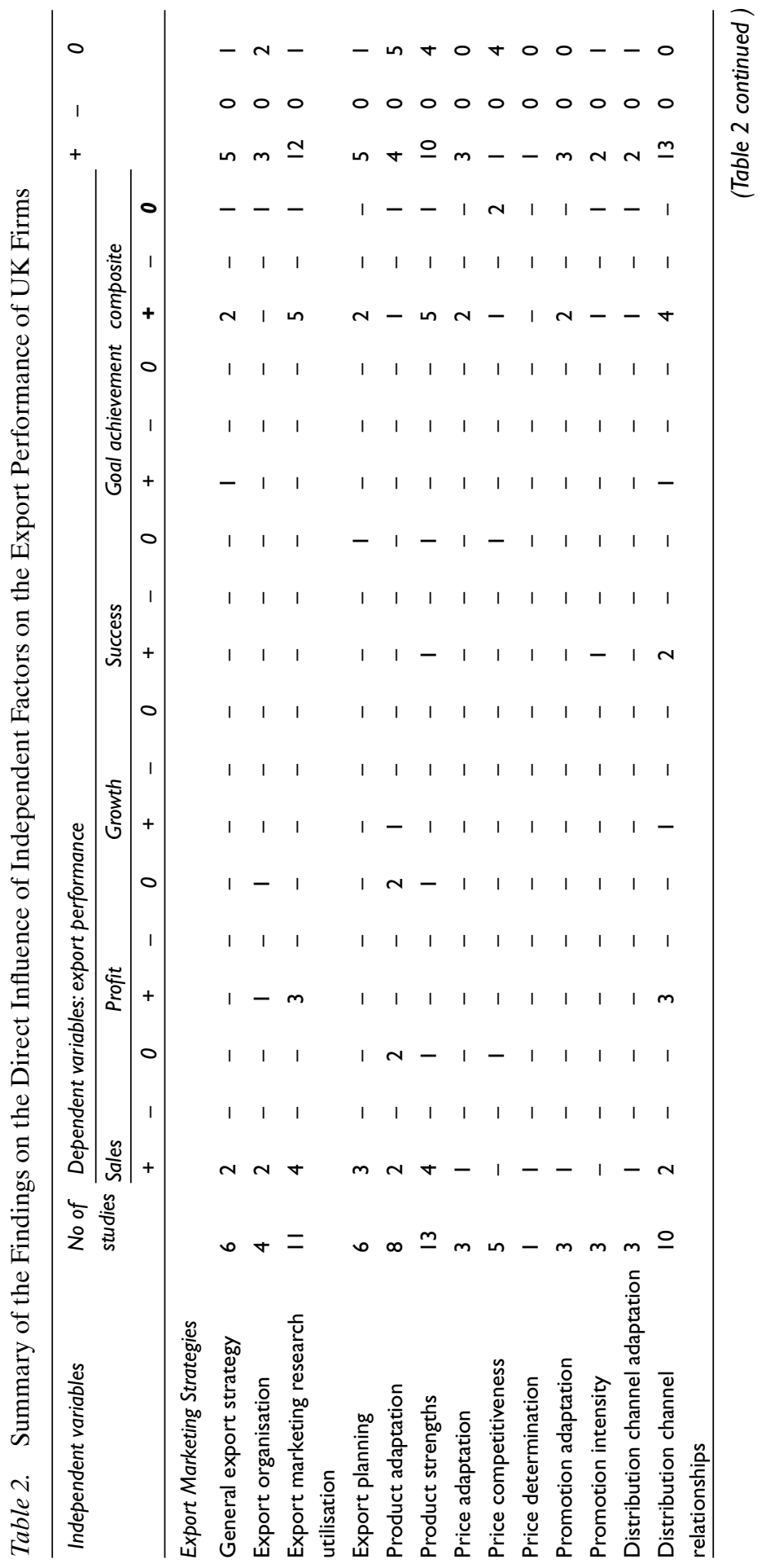


International Small Business Journal 26(2)

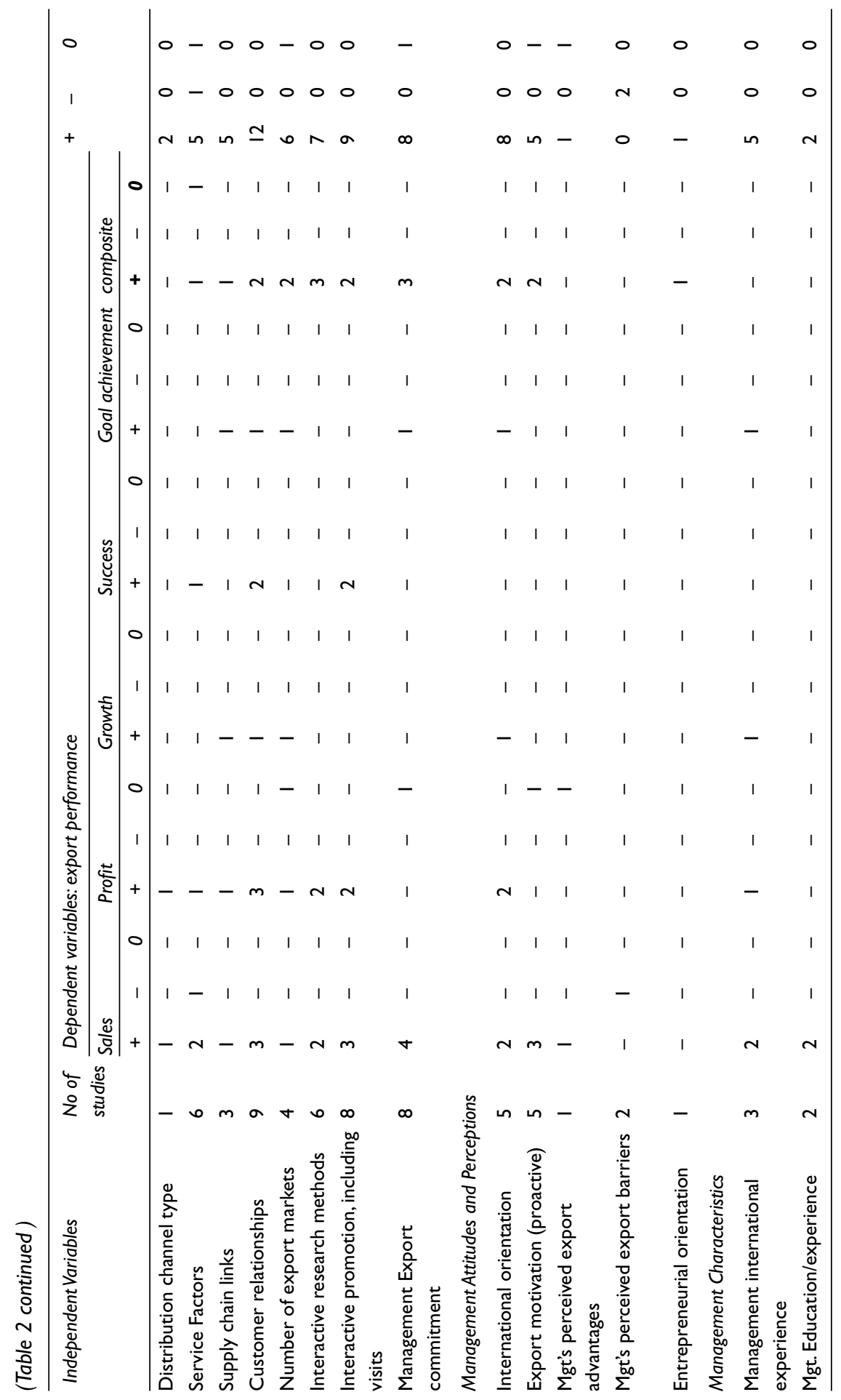


Wheeler et al.: UK Export Performance: Review and Implications

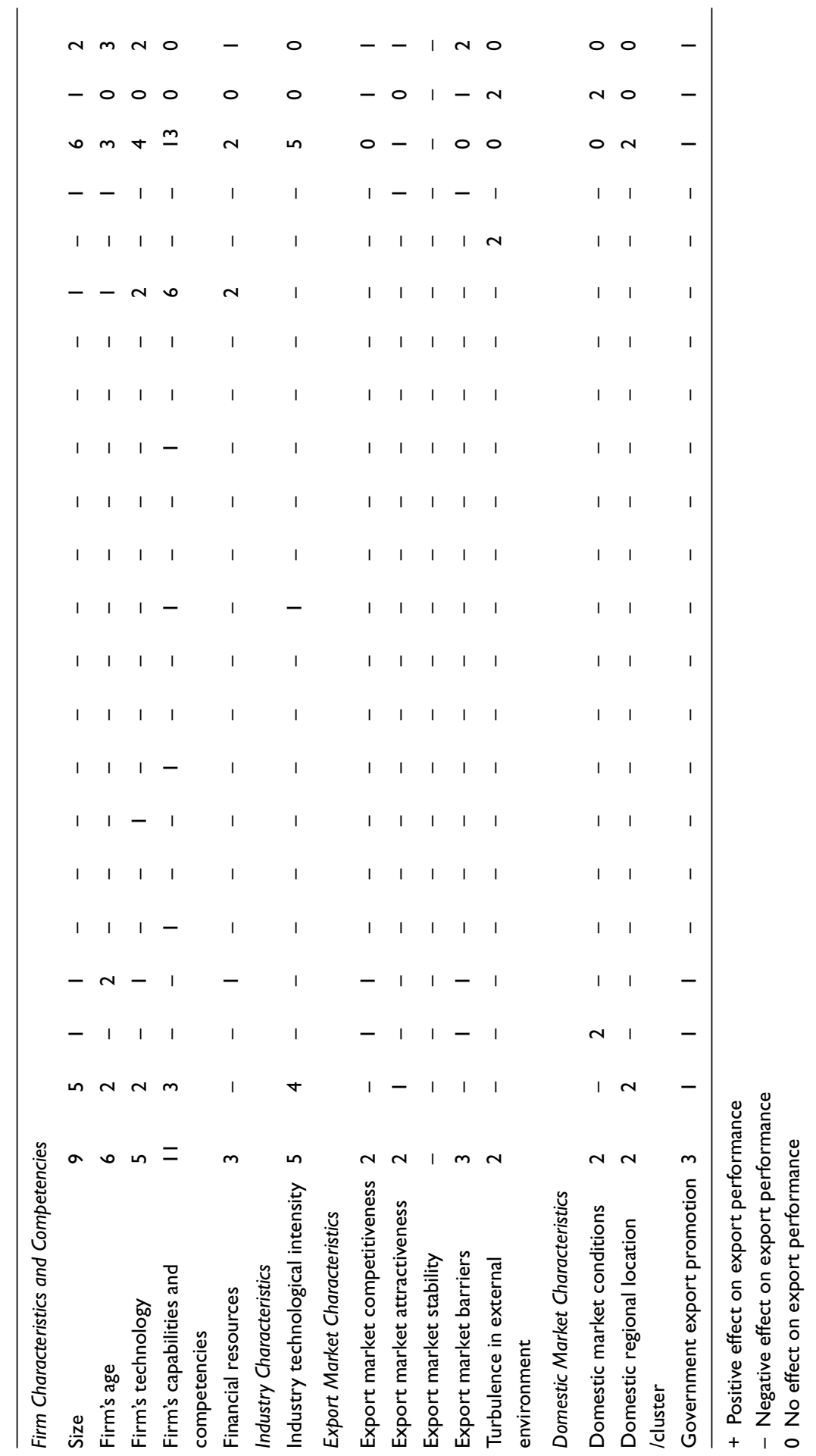


International Small Business Journal 26(2)

namely sales, profits, growth and goal achievement. Related factors, entrepreneurial learning and persistence, were further observed to be associated with future exporting intention in Crick's study of firms that had ceased exporting (Crick, 2004).

Only one of the eight management-related factors investigated, namely management's perception of export barriers, would seem to have a detrimental effect on UK firms' export performance - specifically export sales and the composite measures. This is understandable given that such negative perceptions suggest lower levels of international orientation and experience, and may detract from the amount of commitment and support given by the top management to export ventures and initiatives. It is, indeed, important to highlight that as far as the export performance effects of management-related attributes and resources are concerned, this present review of UK evidence suggests none of those inconsistent and contradictory findings widely reported in previous integrative reviews of export performance research (e.g. Aaby and Slater, 1989).

Altogether, the aggregate results on these factors, as shown in Table 2, agree with the conclusions reached in previous reviews (Aaby and Slater, 1989; Chetty and Hamilton, 1993; Ford and Leonidou, 1991; Leonidou and Katsikeas, 1996; Zou and Stan, 1998). Aaby and Slater (1989), for example, concluded that management commitment and management perceptions and attitudes towards export problems and incentives are good predictors of export success. Ford and Leonidou's (1991) review, which focused on European export performance studies, also concluded that exporters with high-quality, internationally oriented management are more likely to have a successful export business. Equally interesting are the similarities between these conclusions and the findings of earlier empirical studies undertaken in the UK during the 1960s (e.g. Tookey, 1964) and the 1970s (e.g. Betro Trust Committee, 1976; Cunningham and Spigel, 1971; Fenwick and Amine, 1979).

It can, indeed, be argued that this historical consistency provides some kind of longitudinal support for the importance of management-related factors in achieving improved export performance. It seems entirely appropriate, therefore, to conclude that UK companies aiming to achieve improved export performance could benefit from the availability, development or introduction of top management staff that are imbued with the relevant attributes, skills, orientation and resources. Export policy support should continue to focus on such capacity enhancement measures with a view to expanding the cohort of successful exporting firms and boosting overall export performance in the UK.

Firm Characteristics and Resources Firm characteristics and resource base seem to be good determinants of export performance in the UK. As can be seen from Table 2, the UK studies under review investigated five relevant independent factors, including firm size, age, technological and financial resources and other firm-specific capabilities. Aggregate analysis suggests that firm capabilities, size and financial resources have strong, positive effects on various dimensions of export performance, including export sales, profits, growth and goal achievement, as well as the composite measures. This supports Ford and Leonidou's (1991) conclusion regarding the importance of 'financial, manpower, marketing 
and production advantages' associated with larger firm size. It also agrees with the balance of relevant empirical evidence (Chetty and Hamilton, 1993; Miesenbock, 1988), which suggests the importance of size-related capabilities and resource advantages (Keng and Jiuan, 1989; Ogram, 1982; Reid, 1982; Tyebjee, 1994), particularly in initiating international activity (Bilkey, 1978; Reid, 1982; Tybejee, 1994). This aggregate UK evidence adds to the strength and consistency of empirical support for the export performance implications of firm resource base and capabilities, reinforcing the growing realization among international business scholars of the relevance of the resource-based view in explaining the internationalization behaviour of firms (Bell and Young, 1998; Crick and Jones, 2000; Ibeh, 2001; Ibeh and Wheeler, 2005; Jones, 1999).

It is worth noting, however, that findings on a number of independent factors, particularly firm age and technology, are not as consistent and as clear cut as those for firm capabilities, or for the management-related factors discussed earlier. For example, three of the six studies that investigated the relationship between the age of the firm and export performance found a positive association, while three others reported non-significant effects. These mixed findings support the conclusions reached in previous integrative reviews (Aaby and Slater, 1989; Madsen, 1987; Zou and Stan, 1998) that firms' age and technology orientation per se are of less importance in achieving superior export performance. What seems to matter is not for how long (or how short) the firm has been in existence, but its relative success in acquiring key advantage-generating resources and capabilities. For some new firms, in certain sectors, backed by one or more internationally orientated and experienced decision makers (e.g. the MacDougall, Shane, and Oviatt's [1994] international start-ups, or Jones' [1999] international entrepreneurs), this critical resource stockpile may be fast paced leading to accelerated internationalization (Burgel and Murray, 2000; Coviello and Munro, 1997; Crick and Jones, 2000; Madsen and Servais, 1997) and positive export performance. For some others, however (e.g. firms in traditional, culture-bound industries or from large domestic markets), the requisite export-promoting resources/capabilities may take longer to acquire, thus, leading to lower or zero levels of export performance.

The inconclusive evidence on the effects of firm technological level on export performance may be explained by the differences in the industries and markets covered by the UK firms in the reviewed studies. For example, as Bell et al. (2004) suggested, high-tech firms tend to have different internationalization pathways from low-tech firms. Given that technological intensity may have markedly different competitive advantage implications across industries and markets, future researchers seeking to obtain clearer insights into the effect of this factor on export performance are urged to focus on firms from fairly homogenous industries (e.g. the high technology sector), and which target export markets at comparable level of economic development. This, indeed, echoes Zou and Stan's (1998) earlier call for greater consideration for the context in which technology level is studied.

Firm Competencies and Strategies This section discusses aggregate UK findings on the export performance effects of relevant indicators of firm-level competencies and strategies (including export marketing and relational strategies). 
As can be observed from Table 2, some 20 independent factors were investigated in the UK studies reviewed. These include general export strategy, export organization, export planning, export marketing research utilization, product adaptation, product strengths, price adaptation, price competitiveness, price determination, promotion adaptation, promotion intensity, distribution channel adaptation, distribution channel type, service factors, number of export markets, distribution channel relationships, supply chain links, customer relationships, interactive research methods, and interactive promotion, including visits. For greater clarity of analysis, these variables are discussed under appropriate headings employed in previous integrative reviews, namely export marketing strategy (Aaby and Slater, 1989; Zou and Stan, 1998) and relational strategies (Styles and Ambler, 1994).

Export Marketing Strategy In general, the findings reported on aspects of export marketing strategy seem to exhibit the earlier noted inconsistencies of exporting research (Aaby and Slater, 1989; Young, 1995). Nevertheless, several conclusions can be drawn based on Table 2. First, having a defined strategy for the firm's exporting activity appears to be a good predictor of export sales. Although only six studies reported findings on this variable (i.e. general export strategy), the additional favourable evidence obtained on the use of export market diversification strategy and multiple internationalization modes (Crick et al., 2003) from several other UK studies underscores the importance of having a strategic orientation for achieving improved export performance. Further relevant research is needed on this factor, however, in view of the inconclusive nature of the conclusions reached in previous reviews (e.g. Madsen, 1987; Zou and Stan, 1998).

The second important conclusion emerging from the aggregate analysis in Table 2 is that making a deliberate effort in planning and organizing for exporting may lead to improvements in export sales, export profits and in the composite measures of export performance. This finding reflects the balance of previous relevant evidence (Aaby and Slater, 1989; Zou and Stan, 1998) and is easily explained since investment of efforts and resources in export planning and organization suggests commitment to exporting, which tends to be rewarded with favourable export performance. This is without prejudice to the observed role of chance or serendipity in the early internationalization of high-tech SMEs from the UK in more recent work by Crick and Spence (2005), an issue that is taken up in the concluding sections of this article.

Even more strongly supported by the reviewed UK empirical studies are a number of specific strategic factors and competencies, including marketing research utilization, product strength, and service quality. Take marketing research utilization for instance. All but 1 of the 13 findings reported on this variable suggested positive associations with dimensions of export performance (export sales, export profits, and the composite measures). The only non-supportive finding was a notsignificant effect. For product strength there were 10 positive, 4 not-significant and no negative findings. These aggregate results on export market research utilization and product strengths, also shared by previous reviews (Madsen, 1987; Zou and 
Stan, 1998), underscore the overall importance of firms' competitive skills and competencies (Piercy et al., 1998) in delivering superior export performance.

It is, indeed, arguable that the identified competencies are at the heart of competitive advantage, particularly in the international setting. To be sure, export market research utilization generally translates to greater internalisation of relevant knowledge regarding target export markets, including the key actors and influences therein. It makes sense therefore, that firms with requisite competencies in export market intelligence gathering and knowledge management are more likely to develop and offer products and services of appreciably superior quality, and achieve better export performance.

The impact of adaptation strategies on the export performance of UK firms appears to be mixed. As Table 2 shows, some neutral effects were reported for product adaptation and distribution channel adaptation while price and promotion adaptation received some support. This reflects the lack of clear guidance on standardization/adaptation decisions from both the export behaviour and the wider international business literature (Zou and Stan,1998). The findings regarding price competitiveness are, however, more definitive: the mainly not-significant results suggest that UK firms do not use pricing as a competitive tool in their exporting operations, reinforcing previous evidence from studies undertaken in the UK during the 1970s: Cunningham and Spigel (1971) and Michell (1979), for example, reported that successful UK exporters attached less importance to pricing-related variables such as lower price than competition and special discounts.

Relational Strategies Factors pertaining to firms' competencies in managing relationships and leveraging external networks/resources consistently received strong, positive endorsements from the UK studies reviewed. As can be seen from Table 2, all the investigated variables (that is, distribution channel relationships, customer relationships, supply chain links, interactive research methods, and interactive promotional methods, including market visits) seem to have strong positive associations with a range of export performance measures. More specifically, good distribution channel and customer relationships appear to impact favourably on export sales, export profits, export growth, perceived export success, goal achievement and on the composite measures of export performance. The adoption of interactive research methods and interactive promotion (including market visits) also seem to have similarly strong positive effects on all dimensions of export performance apart from growth.

Altogether, these findings strongly underline the importance of relational strategies as critical success factors in exporting. It should be noted that although previous integrative studies (e.g. Madsen, 1987; Zou and Stan, 1998) had concluded on the importance of channel relationships, none had reported a level of consistency and predictive strength comparable to that observed in this UK focused review. This might, indeed, suggest that relationship based strategies have been particularly critical in promoting export performance among UK firms during the period under review. Future integrative reviews of UK exporting research should follow up on this finding, to discover whether these relational variables would remain solidly positive and highly consistent predictors of UK firm export performance 
during the 21st century. Overall, there can be little doubt that firms that develop excellent relationship-creating skills, and which pursue a strategy of deploying such competencies in achieving closely managed - personal, interactive, trusting, longterm - partnerships with foreign distributors, customers, and other relevant market actors are highly likely to gain exporting success (Bell, 1995; Coviello and Munro, 1997; Crick and Jones, 2000; Hellman, 1996).

\section{External Environmental Factors}

Previous effort (e.g. Zou and Stan, 1998) to integrate findings relating to the effects of the external environment on export performance has generally been organized around three categories of factors. These include the industry/market characteristics, the foreign market factors, and the domestic market characteristics. As can be seen from Table 2, few definite conclusions can be drawn on these factors. (The only exceptions are industry technological intensity and proximate location to a relevant cluster of firms). This is because of the mixed nature of the findings and the generally scant attention given to external factors in UK-focused export performance research - mirroring the situation in the broader export performance and international business literature (Rao et al., 1989; Zou and Stan, 1998; Young, 2001).

Industry Characteristics The level of technological intensity in an industry seems to be a good predictor of export performance, with the five UK studies that examined this factor all reporting positive associations. A likely explanation for this is that the global nature of technology-based competition (marked by high R \& D investments, short product life cycles, and so on) requires and challenges success-seeking firms in such sectors to be internationally alert/active, and to explore links aimed at achieving and maintaining their international competitiveness (Crick and Jones, 2000). This finding arguably strengthens the observation made earlier in this article with respect to firm technology level and export performance, that is, technology intensity may yield significant export performance benefits to firms operating in some sectors (e.g. high technology sectors) but may be less important for others competing in more traditional industries (Bell et al., 2004). Industry-wide (rather than firm-level) technological intensity, therefore, appears to be a better predictor of export performance (Oakley, 1996; Wakelin, 1998) among UK firms.

Domestic Market Characteristics The reviewed UK evidence also suggests that regional environment, including membership or proximity to a relevant cluster of firms, may have a favourable impact on export performance. The studies that examined the impact of this factor concluded on the favourable impact of appropriate regional environment (O'Farrell et al.,1998) or embeddedness within a local cluster/network (Keeble et al., 1998) on firm export performance (Westhead, 1995). This adds to the growing body of anecdotal and empirical evidence on the importance of appropriate regional location (or proximity to a relevant cluster of firms) in improving international market performance (Brown and McNaughton, 2000).

Another domestic environment-related factor investigated in a number of the studies under review is the perceived impact of government export promotion programmes. Consistent with the balance of evidence in previous studies 
(see Leonidou, 1995), the findings generally suggest low perceptions of government export promotion programmes among UK firms. Indeed, the three UK studies that examined the factor reported a positive effect, a negative effect and a non-significant effect respectively. This suggests that despite the observed improvements in UK government export support programmes (Crick, 1995), they are still not favourably perceived among exporting firms.

The observed inverse relationships between UK firms' export sales and their perceptions of domestic environmental factors (see Table 2) is worth highlighting. This supports the view of adverse conditions in the domestic market - recession, stagnation, saturation - as 'push' factors associated with higher export performance (Bilkey, 1978; Pavord and Bogard, 1975; Rao et al., 1989). Further research is, however, required given previous contradictory findings (Zou and Stan, 1998) and the scant attention paid to this area in the UK studies reviewed.

Foreign Market Characteristics Of the seven studies that reported evidence on the relationship between perceived export market attractiveness, export market barriers and foreign market turbulence and export performance, all but one indicated either non-significant or negative effects. Styles and Ambler (1994), for example, reported that the high and low performers among UK exporting firms surveyed did not differ significantly in terms of their perceptions of the quality of infrastructure in foreign markets. This reinforces the conclusion reached by Michell (1979) nearly two decades earlier, and adds to the totality of conflicting evidence reported on the above factors in previous exporting research (Madsen, 1987; Zou and Stan, 1998).

The aggregate UK evidence on the effect of export market competitiveness on export performance is also weak. As Table 2 shows, the two studies that investigated this factor respectively reported negative and not significant effects on export sales. Although this evidence aligns with Ford and Leonidou (1991) who found that that keen competition in foreign markets reduces the chances for successful export operations, the conflicting nature of the conclusions reached in other integrative studies (Madsen, 1987; Zou and Stan, 1998) suggests the need for further clarification.

There are grounds, however, to suspect, as this present review suggests, that UK firms find it hard going in highly competitive export markets. In addition to the earlier discussed evidence that UK firms generally attach less importance to price competitiveness and market adaptation, several researchers (Bennett, 1998; McGuinness et al., 1991; Moore, 1990; Williamson, 1991) have concluded that UK firms compare badly with their counterparts from other advanced developed economies. McGuinness et al. (1991), for example, studied the Chinese customers' perceptions of western companies operating in the Chinese market. They found that German and Swiss firms were beginning to supplant Japan at the quality end of the market, while the Italians were moving strongly into the sizeable lower quality, lower priced equipment niche. British firms were perceived to be worst placed: in the middle, with rather high prices and weak promotional and service activities. Williamson (1991) has also attributed the British firms' relatively low and unstable share of total US imports in various product categories to their below 
International Small Business Journal 26(2)

average investment in local sales marketing and distribution infrastructure and much higher price volatility in the US market.

\section{Summary, Conclusions and Implications}

This article has integrated and reviewed findings from previous export performance research undertaken in the UK during the 1990-2005 period. It follows in the tradition of earlier country/region focused meta analyses (Bonaccorsi, 1994; Da Rocha and Christensen, 1994; Ford and Leonidou, 1991; Tesfom and Lutz, 2006), which had sought to understand aspects of export behaviour of firms from a given geopolitical context in order to better inform managerial and policy decisionmaking and facilitate improved outcomes. The study contributes at a number of levels, including being one of the first attempts at consolidating the knowledge base on export performance research in the UK, an effort that seems particularly germane given the observed relative underperformance of British firms in outward internationalization (Beamish et al., 1993; Diamantopoulos and Schlegelmilch, 1994; McGuinness et al., 1991; Morgan and Katsikeas, 1998). Another key contribution relates to the study's approach, which explicitly builds upon previous review models, constructs and independent factors (Aaby and Slater, 1989; Zou and Stan, 1998) and responds to mounting calls for a holistic view of firm internationalization (Bell et al., 2004; Bell et al., 2003; Crick and Spence, 2005; Ibeh, 2001).

Among the main conclusions of the present review are the observed criticality of managerial, resource/competency-related, and relationship-based factors in predicting firm-level export performance; and the mixed, or inconclusive, export performance effects of factors, including firm's age and technology level, marketing mix adaptation, and foreign and domestic market environments. These conclusions are firmly consistent with previous evidence from the wider export behaviour literature (Aaby and Slater, 1989; Young, 1995). Certain distinctive aspects of UK firms' export behaviour were, however, observed, specifically their strong emphasis on relational strategies and little use of pricing and market adaptation as competitive tools. Figure 2, summarizes the review findings.

\section{Theoretical Implications}

The summary framework represents a fair attempt at blending the better aspects of previous relevant models, notably Aaby and Slater's (1989), Styles and Ambler's (1994), and Zou and Stan's (1998). It is also the case that the observed predictors of firm-level export performance in the UK can be explained from several theoretical angles. For example, the importance of managerial and firm-specific resources/ capabilities and competencies in promoting export performance is consistent with the resource-based viewpoint (Barney, 1991; Wernerfelt, 1984) as well as the organizational capability (Madhok, 1997) and strategic management perspectives (Cavusgil and Zou, 1994; Namiki, 1988; Young, 1987). The solidly favourable effects reported for relational strategies similarly echo insights from the network/interaction-based models (Axelsson and Easton, 1992; Johanson and Mattsson, 1988). Even the not-so-well supported external factors include a number of important findings (on the favourable effects of industry technological intensity and appropriate 
FIRM INTERNAL ENVIRONMENT

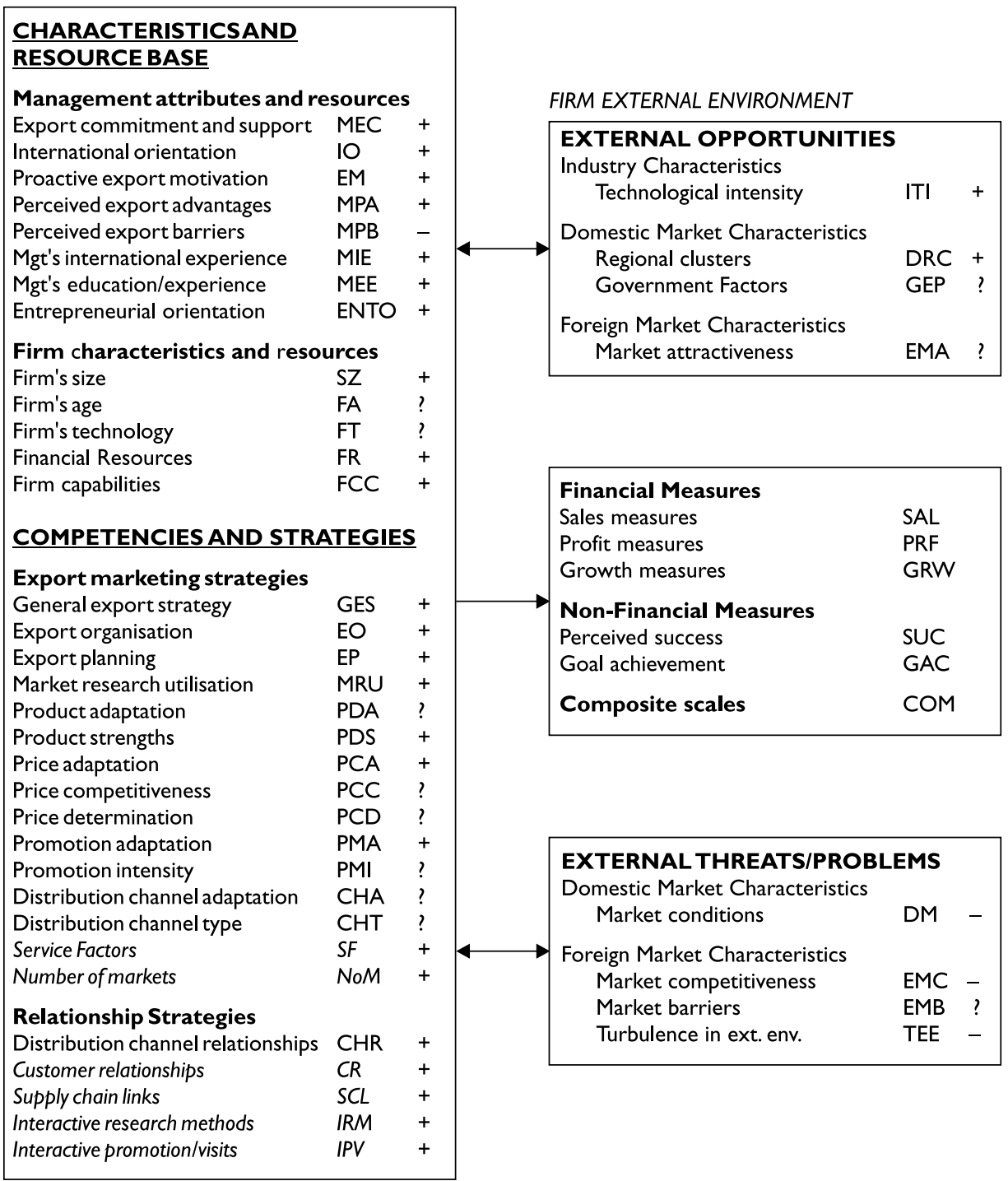

Figure 2. A Summary of Aggregate Findings on the Determinants of Export Performance Among UK Firms

regional location or proximity to a relevant cluster of firms), which underscore the relevance of the industrial organization perspective in studying export performance (Zou and Stan, 1998). The foregoing thus suggests that exporting research has advanced beyond Aaby and Slater's characterization of the field 'as a mosaic of autonomous endeavours' (Aaby and Slater, 1989: 7).

Overall, it can be concluded that the summary findings, in Figure 2, provide considerable support for the view that an enlarged base of complementary theoretical 
perspectives may offer richer insights into firm-level export performance (Bell and Young, 1998; Bell et al., 2004; Bell et al., 2003; Crick and Spence, 2005; Zou and Stan, 1998). It is gratifying also that the considerable effort invested in benchmarking the present study against the major previous reviews of export performance research has yielded a robust integrative framework, which appears to provide a fuller explanation of firm export performance in a UK context.

\section{Managerial and Policy Implications}

The present review findings strongly suggest the need for success-seeking UK exporting firms to prioritize having managerial staff with the appropriate mix of pro-exporting attributes, including international orientation and experience; as well as developing firm-level capabilities in the areas of export market intelligence gathering, knowledge management (e.g. in planning and organizing for exporting), quality product and service delivery, and international relationship management. These conclusions have well-established and widespread empirical support (Aaby and Slater, 1989; Zou and Stan,1998) and should, thus, command the focused attention of UK business leaders, policy makers and other stakeholders (e.g. the Confederation of British Industries [CBI], The Federation of Small Businesses [FSB]) with a keen interest in expanding the cohort of successful British exporting firms and improving the economic health of the UK and its regions. The envisaged intervention should broadly be aimed at targeting customized capacity building solutions particularly at smaller firms to enable them to overcome critical resource gaps that may constrain their international involvement and success. Such a tailored approach seems sensible given previously reported indifferent perceptions of government export support programmes among UK firms (Crick, 1995; Young, 1995).

Another major challenge that demands concerted public and private sector effort concerns the finding that UK firms tend to attach little importance to price competitiveness and market adaptation in their exporting operations. This is consistent with previous evidence from UK studies undertaken during the 1970s (Cunningham and Spigel, 1971; Michell, 1979), with the latter observation on market adaptation seemingly reflecting the observed reluctance of UK firms to develop foreign language competencies (Williams and Chaston, 2004) and their use of similar strategies in both domestic and export markets (Stewart and McAuley, 2000). This observed lack of price competitiveness and market responsiveness may, at least in part, explain why British firms are perceived to compare badly with their counterparts from other advanced developed economies (Bennett, 1998; McGuinness et al., 1991; Moore, 1990; Williamson, 1991). The present authors, thus, call on the UK Trade International and their regional counterparts to work collaboratively with relevant private sector organizations, notably the CBI, FSB, in designing appropriate support initiatives, with the twin aims of sensitizing British exporters about their observed shortcomings and partnering them to develop and implement effective remedial strategies for their various export markets. Such public-private sector collaboration may improve the efficacy of support programmes to the user community and obviate previous characterization of government export assistance as taking a 'scatter-gun' approach (Crick, 1995). It may also lead to the broadening of the spectrum of support 
provision beyond exporting, to reflect the reality of small firms' increasing use of other internationalization modes (Bell et al., 2004; Majocchi and Zucchella, 2003).

\section{Methodological Issues and Future Research Directions}

The present review suggests some methodological advancements in export behaviour research since the last major integrative effort in the late 1990s (Zou and Stan, 1998). These include an increasing use of explicit theoretical frameworks and further progress towards complementary and holistic explanations (as opposed to the competing explanations observed by Zou and Stan, 1998). That said, several previously highlighted methodological concerns still persist, including the preponderant focus on the firm, rather than the product-market, as the unit of analysis in exporting research; the insufficient application of multivariate data analysis techniques and less-than-robust definition, measurement and testing procedures for key constructs and independent factors; the relative neglect of, and inconsistent specification, of external environmental factors; the lack of clarity on the factors that have direct effects on export performance and those with indirect effects; the continuing lack of agreement on, and use of disparate, measurement scales for export performance and independent factors (Lages and Lages, 2004; Sousa, 2004); the relatively low usage of non-financial and subjective measures of export performance, including perceived 'satisfaction' (Jones and Crick, 2001; Sousa, 2004); and the low incidence of longitudinal research and coverage of service exporting.

Future researchers are urged to address the areas of concerns mentioned earlier, by, among other things, heeding earlier calls to focus on the product-market level as their unit of analysis (Sousa, 2004; Styles and Ambler, 1994); undertaking more longitudinal research to deepen understanding of the processes involved in developing capabilities and competences; using multivariate data analysis techniques wherever feasible, with appropriate control variables, improved construct measurement and properly stated validity, reliability and error levels (Zou and Stan, 1998); providing better specification of the nature of the effects - direct or indirect of particular independent factors on export performance (Zou and Stan, 1998; Williams and Chaston, 2004); making more regular use of qualitative approaches particularly for theory development; employing appropriate or multiple measures of export performance, including subjective and non-financial options such as perceived 'satisfaction' (Crick and Jones, 2001; Sousa, 2004); and studying more service exporters.

Researchers should also prioritise studies with explicit export performance implications in view of their greater potential to guide policy and managerial decision-making. This last point may be particularly helpful in improving the knowledge base on the effects of Internet usage on UK export performance, as a complement to recent research that has mainly examined the role of the Internet on firm's international activities (Bennett, 1997, 1998; Hamill and Gregory, 1997; Morgan-Thomas and Bridgewater, 2004). Other interesting research issues that should be further investigated include the impact of the recent enlargement of the European regional market on firms' international performance; the role of planned and unplanned strategies on firms' international success (Crick and Spence, 2005); and the effects, if any, of export discontinuation or de-internationalization events 


\section{International Small Business Journal 26(2)}

on future international performance of firms (Crick, 2004). Finally, researchers in the exporting field are encouraged to direct more attention on the increasingly important 'international performance' construct in view of the increasing tendency among firms, including smaller firms, to employ non-exporting or multiple modes of internationalization (Bell et al., 2004; Majocchi and Zuchella, 2003).

\section{References}

Aaby, N. and Slater, S.F. (1989) 'Management Influences on Export Performance: A Review of the Empirical Literature 1978-1988', International Marketing Review 6(4): 7-23.

Axelsson, B. and Easton, G. (eds) (1992) Industrial Networks: A New View of Reality. London: Routledge.

Balabanis, G. and Katsikea, E. (2003) 'Being an Entrepreneurial Exporter: Does it Pay?', International Business Review 12(2): 233-52.

Balabanis, G. and Diamantopoulos, A. (2004) 'Domestic Country Bias, Country-of-Origin Effects, and Consumer Ethnocentrism: A Multidimensional Unfolding Approach', Journal of the Academy of Marketing Science 32(1): 80-95.

Barney, J. (1991) 'Firm Resources and Sustained Competitive Advantage', Journal of Management 17(1): 99-120.

Beamish, P. W., Craig, R. and McLellan, K. (1993) 'The Performance Characteristics of Canadian versus U.K. Exporters in Small and Medium-sized Firms', Management International Review 33(2): 121-37.

Bell, J. (1995) 'The Internationalization of Small Computer Software Firms: A Further Challenge to Stage Theories', European Journal of Marketing 29(8): 60-75.

Bell J., Crick D. and Young S. (2004) 'Small Firm Internationalization and Business Strategy: An Exploratory Study of Knowledge-Intensive and Traditional Manufacturing Firms in the UK', International Small Business Journal 22 (1): 23-56.

Bell, J., McNaughton R., Young, S. and Crick D. (2003) 'Towards an Integrative Model of Small Firm Internationalization', Journal of International Entrepreneurship 1(4): 339-62.

Bell, J. and Young, S. (1998) 'Towards an Integrative Framework of the Internationalization of the Firm', in G. Hooley, R. Loveridge and D. Wilson (ed.) Internationalization: Process, Context and Markets, pp. 5-28. London: Macmillan.

Bennett, R. (1997) 'Export Marketing and the Internet', International Marketing Review 14(5): 324-44.

Bennett, R. (1998) 'Using the WWW for International Marketing: Internet Use and Perceptions of Export Barriers among German and British Businesses', Journal of Marketing Communications 4(1): 27-43.

Betro Trust Committee, (1976) Concentration on Key Markets. London: Royal Society of Arts.

Bilkey, W. J. (1978) 'An Attempted Integration of the Literature on the Export Behavior of Firms', Journal of Internal Business Studies 9(Spring-Summer): 33-46.

Bonaccorsi, A. (1993) 'What Do We Know about Exporting by Small Italian Manufacturing Firms', Journal of International Marketing 1(3): 49-75.

Brown, R. and Cook, D. (1990) 'Strategy and Performance in British Exporters', The Quarterly Review of Marketing 15(3): 1-6.

Brown P. and McNaughton R. (2000) 'Cluster Development Programmes: Panacea or Placebo for Promoting SME Growth and Internationalization', paper presented at Second Biennial McGill Conference on International Entrepreneurship: Researching Frontiers, 23-5 September. 
Burgel, O. and Murray, G. C. (2000) 'The International Market Entry Choices of Start-Up Companies in High-Technology Industries', Journal of International Marketing 8(2): $33-62$.

Cavusgil, S. T. and Zou, S. (1994) 'Marketing Strategy-Performance Relationships: An Investigation of the Empirical Link in Export Market Ventures',Journal of Marketing 58(1): $1-21$.

Chetty, S. K. and Hamilton, R. T. (1993) 'Firm-level Determinants of Export Performance: A Meta-analysis', International Marketing Review 10(3):26-34.

Collis, D. (1991) 'A Resource-Based Analysis of Global Competition: The Case of the Bearings Industry', Strategic Management Journal 12(Special Issue): 49-68.

Coviello, N. and McAuley, A. (1999) 'Internationalization and the Smaller Firm: A Review of Contemporary Empirical Research', Management International Review 39(3): 223-56.

Coviello, N. and Munro, H. (1997) 'Network Relationships and the Internationalization Process of Small Software Firms', International Business Review 6(4):361-86.

Crick D. (2004) 'U.K. SMEs' Decision to Discontinue Exporting: An Exploratory Investigation into Practices within the Clothing Industry', Journal of Business Venturing 19(4): $561-87$.

Crick, D. (1995) 'An Investigation into the Targeting of UK Export Assistance', European Journal of Marketing 29(8): 76-94.

Crick, D. and Bradshaw, R. (1999) 'The Standardisation Versus Adaptation Decision of "Successful" SMEs: Findings from a Survey of Winners of the Queen's Award for Export', Journal of Small Business and Enterprise Development 6(2): 191-9.

Crick, D., Bradshaw, R. and Chaudhry, S. (2002) 'An Investigation into the Overseas Market Servicing Strategies of Queen's Award for Export Winners: Revisiting the Concentration versus Spreading Debate', Marketing. Intelligence and Planning 20(6):370-7.

Crick, D., Chaudhry, S. and Batstone, S. (2000) 'Revisiting the Concentration Versus Spreading debate as a Successful Export Growth Strategy: The Case of UK SMEs Exporting Agricultural-related Products', Entrepreneurship \& Regional Development 12(1): 49-67.

Crick D., Chaudhry, S. and Bradshaw R (2003) 'The Overseas Marketing Performance of "Successful" Small U.K. High-Technology Firms: An Exploratory Study Comparing Indigenous and Subsidiary Firms' Competitiveness', Journal of Strategic Change 12(8): 421-33.

Crick, D. and Jones, M. (1999) 'Design and Innovation Strategies within Successful HighTech Firms', Marketing Intelligence and Planning 17(3): 161-8.

Crick, D., Jones, M. and Hart, S. (1994) 'International Marketing Research Activities of UK Exporters: An Exploratory Study', Journal of Euromarketing 3(2): 7-26.

Crick, D. and Jones, M. V. (2000) 'Small High-Technology Firms and International HighTechnology Markets', Journal of International Marketing 8(2): 63-85.

Crick, D. and Katsikeas, C.S. (1995) 'Export Practices of UK Clothing and Knitwear industry', Marketing Intelligence and Planning 13(7): 13-22.

Crick D. and Spence M. (2005) 'The Internationalization of "High Performing" U.K. HighTech SMEs: A Study of Planned and Unplanned Strategies', International Business Review 14(2): 167-85.

Cunningham, M.T. and Spigel, R. I. (1971) 'A Study in Successful Exporting', British Journal of Marketing 1(Spring): 2-12.

Da Rocha, A. and Christensen, C. (1994) 'The Export Experience of A Developing Country: A Review of Empirical Studies of Export Behaviour and the Performance of Brazilian Firms', in S. T. Cavusgil and C. Axinn (eds) Advances in International Marketing Volume 6, pp. 111-42. Greenwich, CT: JAI Press. 


\section{International Small Business Journal 26(2)}

Das, M. (1994) 'Successful and Unsuccessful Exporters from Developing Countries: Some Preliminary Findings', European Journal of Marketing 28(12): 19-23.

Diamantopoulos, A. and Schlegelmilch, B. (1994) 'Linking Export Manpower to Export Performance: A Canonical Regression Analysis of European and U.S. Data', in S. T. Cavusgil and C. Axinn (eds) Advances in International Marketing Volume 6, pp. 161-81. Greenwich, CT: JAI Press.

Dunning, J. (1988) Explaining International Production. London: Unwin Hyman.

Eyre, P. and Smallman, C. (1998) 'Euromanagement Competencies in Small and Mediumsized Enterprises: A Development Path for the New Millennium?', Management Decision 36(1): 34-42.

Fahy, J. (2001) 'A Resource-based Analysis of Sustainable Competitive Advantage in a Global Environment', International Business Review 11(1): 57-78.

Fenwick, I. and Amine, S. (1979) 'Export Performance and Export Policy: Evidence from the U.K. Clothing Industry', Journal of the Operational Research Society 30(8): 747-54.

Ford, D. and Leonidou, L. (1991) 'Research Developments in International Marketing A European Perspective', in S. J. Paliwoda (ed.) New Perspectives on International Marketing, pp. 3-32. London: Routledge.

Freel, S. (2000) 'Do Small Innovating Firms Outperform Non-innovators?', Small Business Economics 14(3): 195-210.

Hamill, J. and Gregory, K. (1997) 'Internet Marketing in the Internationalization of UK SMEs', Journal of Marketing Management 13(1-3): 9-28.

Hart, S. and Tzokas, N. (1999) 'The Impact of Marketing Research Activity on SME Export Performance: Evidence from the UK', Journal of Small Business Management 37(2): 63-76.

Hellman, P. (1996) 'The Internationalization of Finnish Financial Service Companies', International Business Review 3(2): 191-207.

Holzmuller, H. and Stottinger, B. (1996) 'Structural Modeling of Export Success Factors - Cross Validation and further development of an Export Performance Model', Journal of International Marketing 4(2): 29-55.

Ibeh, K. (2001) 'On the Resource-based, Integrative View of Small Firm Internationalization: An Exploratory Study of Nigerian Firms', in J.Taggart, M. Berry and M. McDermott (eds) Multinationals in the New Era, pp. 72-87. London: Macmillan.

Ibeh, K. and Wheeler, C. (2005) 'A Resource-Centred Interpretation of Export Performance', International Journal of Entrepreneurship and Management 1(4): 383-403.

Johanson, J. and Mattsson, L. G. (1988) 'Internationalization in Industrial Systems: A Network Approach', in N. Hood and J.-E. Vahlne (ed.) Strategies in Global Competition, pp. 287-314. Kent: Croom Helm.

Jones, M. V. (1999) 'The Internationalization of Small High Technology Firms', Journal of International Marketing 7(4): 15-41.

Jones, M. V. and Crick D. (2001) 'High-Technology Firms Perceptions of Their International Competitiveness', Journal of Strategic Change 10(3): 129-38.

Katsikeas, C. S., AL-Khalifa, A. and Crick, D. (1997) 'Manufacturers' Understanding of their Overseas Distributors: The Relevance of Export Involvement', International Business Review 6(2): 147-63.

Keeble, D., Lawson, C., Lawton Smith, H., Moore, B. and Wilkinson, F. (1998) 'Internationalization Processes, Networking and Local Embeddedness in TechnologyIntensive Small Firms', Small Business Economics 11(4): 327-42.

Keng, K. A. and Jiuan, T.S. (1989) 'Differences Between Small and Medium Sized Exporting and Non-Exporters: Nature or Nurture', International Marketing Review 6(4): 27-40.

Lages, L. and Lages, C. (2004) 'The STEP Scale: A Measure of Short-Term Export Performance Improvement', Journal of International Marketing 12(1):36-56. 


\section{Wheeler et al.: UK Export Performance: Review and Implications}

Leonidou, L. C. (1995) 'Export Stimulation Research: Review, Evaluation, and Integration', International Business Review 4(2): 133-56.

Leonidou, L. C. and Katsikeas, C. S. (1996) 'The Export Development Process: An Integrative Review of Empirical Models', Journal International Business Studies 27(3): 517-49.

McAuley, A. (1999) 'Entrepreneurial Instant Exporters in the Scottish Arts and Craft Sector', Journal International Marketing 7(4): 67-82.

McDougall, P., Shane, S. and Oviatt, B. (1994) 'Explaining the Formation of International New Ventures', Journal of Business Venturing 9(6): 469-87.

McGuinness, N., Campbell, N. and Leontiades, J. (1991) 'Selling Machinery to China: Chinese Perceptions of Strategies and Relationships', Journal of International Business Studies 22(2): 187-207.

Madhok, A. (1997) 'Cost, Value and Foreign Entry Market Mode: The Transaction and the Firm', Strategic Management. Journal 18(1): 39-61

Madsen T.K.(1987) 'Empirical Export Performance of Studies:A Review of Conceptualisations and Findings', in S. T. Cavusgil (ed.) Advances in International Marketing Volume 2, pp. 177-98. Greenwich, CT: JAI Press.

Madsen, T. K. and Servais, P. (1997) 'The Internationalization of Born Globals: An Evolutionary Process?', International Business Review 6(6): 561-83.

Majocchi, A. and Zucchella, A. (2003) 'Internationalization and Performance: Findings From a Set of Italian SMEs', International Small Business Journal 21(3): 249-68.

Matthyssens, P. and Pauwels, P. (1996) 'Assessing Export Performance Measurement', in S. T. Cavusgil and T. K. Madsen (ed.) Advances in International Marketing Volume 8, pp. 59-84. Greenwich, CT: JAI Press.

Michell, P. (1979) 'Infrastructure and International Marketing Effectiveness', Columbia Journal of World Business 14(1): 91-101.

Miesenbock, K. J. (1988) 'Small Business and Exporting: A Literature Review', International Small Business Journal 6(2): 42-61.

Mole, K. and Worrall, L. (2001) 'Innovation, Business Performance and Regional Competitiveness in the West Midlands: Evidence from the West Midlands Business Survey', European Business Review 13(6): 353-64.

Moore, R. A. (1990) 'The Conflict Gap in International Channel Relationships', Journal of Marketing Management 6(3): 225-37.

Morgan, R. E. and Katsikeas, C. S. (1998) 'Exporting Problems of Industrial Manufacturers', Industrial Marketing Management 27(2): 161-76.

Morgan, N., Zou, S., Vorhies, D. and Katsikeas, C. S. (2003) 'Experiential and Informational Knowledge, Architectural Marketing Capabilities, and the Adaptive Performance of Export Ventures: A Cross-National Study', Decision Sciences 34(2): 287-319.

Morgan-Thomas, A. and Bridgewater, S. (2004) 'Internet and Exporting: Determinants of Success in Virtual Channels', International Marketing Review 21(4-5):393-408.

Namiki, N. (1988) 'Export Strategy for Small Business', Journal of Small Business Management 26(2): 32-7.

O'Farrell, P. N., Wood, P. and Zheng, J. (1998) 'Regional Influences on Foreign Market Development by Business Service Companies: Elements of a Strategic Context Explanation', Regional Studies 32(1): 31-48.

Oakley, P. (1996) 'High-tech NPD Success through Faster Overseas Launch', European Journal of Marketing 30(8): 75-91.

Ogram, E. (1982) Exporters and Non-exporters: A Profile of Small Manufacturing Firms in Georgia', in M. R. Czinkota and G. Tesar, (eds) Export Management: An International Context, pp. 70-84. New York: Praeger.

Pavord, W. C. and Bogart, R. G. (1975) 'The Dynamics of the Decision to Export', Akron Business and Economic Review 6 (Spring): 6-11. 


\section{International Small Business Journal 26(2)}

Piercy, N., Kaleka, A. and Katsikeas, C. S. (1998) 'Sources of Competitive Advantage in High Performing Exporting Companies', Journal of World Business 33(4): 378-93.

Porter, M. E. (1990) The Competitive Advantage of Nations. New York: Free Press.

Rao, C. P., Erramilli, M. K. and Ganesh, G. K. (1989) 'Impact of Domestic Recession on Export Marketing Behaviour', International Marketing Review 7(2): 54-65.

Reid, S. (1982) 'The Impact of Size on Export Behavior in Small Firms', in M. R. Czinkota and G. Tesar (eds) Export Management: An International Context, pp. 18-38. New York: Praeger.

Roper, S. and Love, J. H. (2002) 'Innovation and Export Performance: Evidence from UK and German Manufacturing Plants', Research Policy 31(7):1087-102.

Scherer, F. M. and Ross, A. G. (1990) Industrial Market Structure and Economic Performance. Chicago, IL: Rand McNally.

Souchon, A. and Durden, G. (2002) 'Making the most out of Export Information: An Exploratory Study of UK and New Zealand Exporters', Journal of Euromarketing 11(4): $65-86$.

Sousa, C. (2004) 'Export Performance Measurement: An Evaluation of the Empirical Research in the Literature', Academy of Marketing Science Review 9: 1-22.

Spence, M. (2003) 'Evaluating Export Programmes: UK Overseas Trade Missions and Export Performance', Journal of Small Business Economics 20(1): 83-103.

Stewart, D. and McAuley, A. (2000) 'Congruence of Domestic and Export Marketing Strategies: An Empirical Investigation of its performance Implications', International Marketing Review 17(6): 563-85.

Stottinger, B. and Holzmuller, H. (2001) 'Cross-national Stability of an Export Performance Model: A Comparative Study of Austria and the US', Management International Review 41(1): 7-30.

Styles, C. (1998) 'Export Performance Measures in Australia and the UK', Journal of International Marketing 6(3): 12-36.

Styles, C. and Ambler, T. (1994) 'Successful Export Practice: The U.K. Experience', International Marketing Review 11(6): 23-47.

Styles, C. and Ambler, T. (2000) 'The Impact of Relational Variables on Export Performance: An Empirical Investigation in Australia and the UK', Australian Journal of Management 25(3): 261-81.

Sullivan, D. and Bauerschmidt, A. (1989) 'Common Factors Underlying Barriers to Export: A Comparative Study in the European and US Paper Industry', Management International Review 29(2): 17-32.

Tesfom, G. and Lutz, C. (2006) 'A Classification of Export Marketing Problems of Small and Medium Sized Manufacturing Firms in Developing Countries', International Journal of Emerging Markets 1(3): 262-81.

Tookey, D. A. (1964) 'Factors Associated with Success in Exporting', Journal of Management Studies 1(1): 48-66.

Tyebjee, T. T. (1994) 'Internationalization of High Tech Firms: Initial vs. Extended Involvement', Journal of Global Marketing 7(4): 59-81.

Tzokas, N., Hart S., Argouslidis, P. and Saren, M. (2000) 'Industrial Export Pricing Practices in the United Kingdom', International Marketing Management 29(3): 191-204.

Wakelin, K. (1998) 'Innovation and Export Behaviour at the Firm Level', Research Policy 26(7-8): 829-41.

Wernerfelt, B. (1984) 'A Resource-based View of the Firm', Strategic Management Journal 5(2): 171-80.

Westhead, P. (1995) 'Exporting and Non-exporting Small Firms in Great Britain', International Journal of Entrepreneurial Behaviour and Research 1(2): 6-36. 


\section{Wheeler et al.: UK Export Performance: Review and Implications}

Westhead, P., Wright, M. and Ucbarasan, D. (2004) 'Internationalization of Private Firms: Environmental Turbulence and Organizational Strategies and Resources', Entrepreneurship and Regional Development 16(6): 501-22.

Westhead, P., Wright, M. and Ucbarasan, D. (2001) 'The Internationalization of New and Small Firms: A Resource-Based Review', Journal of Business Venturing 16(4): 333-58.

Whitelock, J. and Jobber, D. (1999) 'An Exploratory Investigation into the Impact of Competitor Environment and the Role of Information on the Decision to enter a New, Non-Domestic Market', Journal of Global Marketing 13(2): 67-83.

Williams, J. and Chaston, I. (2004) 'Links between the Linguistic Ability and International Experience of Export Managers and their Export Marketing Intelligence Behaviour', International Small Business Journal 22(5): 463-86.

Williamson, P. (1991) 'Successful Strategies for Export', Long Range Planning 24(1): 57-63.

Young, S. (1987) 'Business Strategy and the Internationalization of Business: Recent Approaches', Managerial and Decision Economics 8: 31-40.

Young, S. (1995) 'Export Marketing: Conceptual and Empirical Developments', European Journal of Marketing 29(8): 7-16.

Young, S. (2001) 'What do Researchers know about the Global Business Environment?', International Marketing Review 18(2): 120-9.

Zahra, S., Neubaum, D. and Huse, M. (1997) 'The Effect of the Environment on Export Performance among Telecommunications New Ventures', Entrepreneurship Theory and Practice 22(1): 25-46.

Zou, S. and Stan, S. (1998) 'The Determinants of Export Performance:A Review of the Empirical Literature between 1987 and 1997', International Marketing. Review 15(5):333-56.

Zou, S., Taylor, C. R. and Osland, G. E. (1998) 'The Experf Scale: A Cross-National Generalised Export Performance Measure', Journal of International Marketing 6(3):37-58.

COLINWHEELER is Professor of Marketing at Portsmouth Business School. His research interests include international marketing strategy, the internationalization of the small and medium sized firm and export performance.Address: Portsmouth Business School, University of Portsmouth, Richmond BIdg, Portland Street, Portsmouth POI 3DE, UK. [email:colin.wheeler@port.ac.uk]

KEVIN IBEH is Professor of Marketing and International Business in the Department of Marketing at the University of Strathclyde and is Deputy Director of the Strathclyde International Business Unit. His research interests encompass exporting and international entrepreneurship among smaller firms, including agribusiness firms, developing country firms, and micro-multinationals. Address: Department of Marketing, University of Strathclyde, Cathedral Street, Glasgow, G4 ORQ, UK. [email: k.i.n.ibeh@strath.ac.uk]

PAVLOS DIMITRATOS is a Lecturer at the Department of Management and Technology, the Athens University of Economics and Business, Greece. His research interests relate to international management and strategy, and international entrepreneurship. Address: Athens University of Business and Economics, Athens, Greece.Address: Department of Management Science and Technology, Athens University of Economics and Business, 76, Patission Avenue, 10434 Athens, Greece. [email: pdimitr@aueb.gr] 